\title{
CONF-960421--18
}

\section{NATURAL VENTILATION OF AN EXOTHERMIC WASTE REPOSITORY}

\author{
George Danko \\ Mackay School of Mines \\ University of Nevada, Reno \\ Reno, NV 89557 \\ (702) $784-4284$
}

\section{ABSTRACT}

A scoping calculation is provided to analyze the natural ventilation of a potential exothermic repository. Assuming a current conceptual repository system, a natural air flow rate of $0.6-0.8 \mathrm{~m}^{3} / \mathrm{s}$ is expected due to natural buoyancy-driven ventilation. This air quantity can reduce the maximum repository temperatures significantly.

\section{INTRODUCTION}

A subsurface nuclear waste repository represents a classical thermosiphon arrangement of heat sources (the nuclear waste packages) at low elevation, and a heat sink (the natural surface environment) at higher elevation. Consequently, a positive buoyancy pressure difference can be produced in a recirculating air loop. This natural pressure difference, also referred to as the chimney effect. can drive air, without the assistance of electrical fans, through the air distribution system which includes air filters and the emplacement drifts. Natural ventilation may provide a cost-efficient method to engineer heat and moisture transfer, and improve the overall thermal performance of a high level nuclear waste repository.

The air circulation caused by natural ventilation in the emplacement drifts can be calculated in a similar manner to methods developed for forced ventilation calculations. using performance curve analysis. For natural ventilation. the fan performance characteristics of forced ventilation will be replaced by the functional relationship between buoyancy pressure difference and air flow rate. The airway resistance curve of an emplacement drift will be calculated
RECEVI:

Steven Saterlie

TRW

101 Convention C. Dr.

Las Vegas, NV 89109

(702) 794-7534

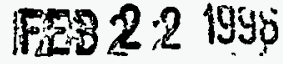

OST.I from the physical charcteristics of the entrance, using the same method applied in forced ventilation calculations.

\section{BUOYANCY PRESSURE CHARACTERISTICS}

The buoyancy pressure difference for a natural ventilation model can be formulated based on the energy balance of an exothermic waste repository. It is convenient to stipulate some simplifying assumptions as follow:

1. Dry repository

2. Isothermal air columns in the intake and exhaust shafts

3. Horizontal emplacement layout at a depth of $300 \mathrm{~m}$ below surface

4. The portion of waste heat dissipated-into the ventilating air, $q_{\text {air }} / q_{\text {packaye, }}$ is expressed by an empirical regression obtained from a complete thermal analysis of a repository under ventilation as follows:

$$
\frac{\mathrm{q}_{\text {air }}}{\mathrm{q}_{\text {package }}}=0.03 * \mathrm{Q}+0.15
$$

where $Q$ is the air flow rate in $\mathrm{m}^{3} / \mathrm{s}, \mathrm{q}_{\mathrm{air}}$ is the fraction of heat dissipated into the air, and $q_{\text {package }}$ is the total dissipation of a package.

Equation (1) was obtained from the results of a thermal study assuming drift emplacement and ventilation (Danko. 1992). In the ratio of $q_{\text {air }} / q_{\text {package }}, q_{\text {air }}$ was calculated from the air temperature increase for a $1000 \mathrm{~m}$-long drift for different air flow rates, while $q_{\text {package }}$ was substituted for the total dissipation of the waste packages over the same drift length. The $\mathrm{q}_{\text {air }} / \mathrm{q}_{\text {packaye }}$ ratio exhibited only a slight 
variation with time over a 100 year time interval, therefore, it was averaged, allowing to use Equation (l) timeindependently. Consequently, natural ventilation calculations can be conducted at any time instant using the projected, instantaneous waste package dissipation at any given time as a driving force.

In general. the buoyancy pressure difference, $\Delta p$, can be expressed by the area bounded by the air density function integrated with respect to elevation, $h$, as follows:

$$
\Delta p=g * \int \rho[T(h)] d h
$$

In Equation (2) the density, $\rho[T(h)]$, can be expressed by a polynomial function of the air temperature, $T$, fit to the data in a standard air properties table. In a range of $260 \mathrm{~K}$ $360 \mathrm{~K}$, a third-order polynomial was applied as follows:

$$
\begin{aligned}
\rho[T(h)]= & -0.00000003912 * T^{j}+0.0000487 * T^{2} \\
& -0.0226 * T+4.6304
\end{aligned}
$$

The air temperature in Equation (3) can be calculated by solving the differential calorimetric equation:

$$
\frac{d t}{d x}=\frac{q_{\text {air }} / q_{\text {package }}}{\rho^{*} c_{p} * Q} * \frac{q_{p s c k a g e}}{\Delta x}
$$

where $\Delta x$ is the waste package spacing, and $c_{p}$ is the specific heat for air at constant pressure, expressed similarly to the density function by a polynomial as follows:

$$
\begin{aligned}
c_{p}[T(h)] & =-0.0000006944 * T^{j} \div 0.0010208 * T^{2} \\
& -0.385 * T+1048.705
\end{aligned}
$$

An input air temperature of $299 \mathrm{~K}$ was assumed for the temperanure boundary condition for the solution of Equation (4). The air temperature increase along a $1000 \mathrm{~m}$ long emplacement drift was calculated numerically as a function of air quantity, $Q$, which was varied between 0.3 and $8 \mathrm{~m}^{3} / \mathrm{s}$, a wide range within which a unique value is to be calculated. With the assumptions of isothermal air columns in the $300 \mathrm{~m}$-deep intake and exhaust shafts, the buoyancy pressure difference integral in Equation (2) can be calculated as a rectangular area:

$$
\Delta p=300 * g *\left(\rho_{\max }-\rho_{\min }\right)
$$

where $g=9.81 \mathrm{~m} / \mathrm{s}^{2}$, and $\rho_{\max }$ and $\rho_{\min }$ are calculated with the air temperatures in the intake and exhaust shafts, using Equation (3).
In order to evaluate the buoyancy pressure characteristics of natural ventilation, numerical calculations, based on the solution of Equation (4), were repeated with five different waste package dissipations of 7283 , $6218,5310,3765$, and $2223 \mathrm{~W}$, corresponding to the time instants of $0.5,5,20,50$, and 100 years. The results for $\Delta p$ and the corresponding air temperature differences between the intake and exhaust air are shown in Figure $!$ as a function of air flow rate, $Q$.

Estimates of the air flow rate due to natural ventilation can be obtained using characteristic curves of the buoyancy pressure difference, $\Delta \mathrm{p}$, versus air flow, $\mathrm{Q}$. The intersections of the $\Delta \mathrm{p}-\mathrm{Q}$ curves with the ventilating air flow resistance curve for a drift, distribution, and filter system provide the working points for natural ventilation.

\section{FLOW RESISTANCE CHARACTERISTICS}

The dominant element of the air flow resistance comes from the pressure loss across the air filters. A rule-ofthumb pressure loss of $1000 \mathrm{~N} / \mathrm{m}^{2}$ is assumed at $1 \mathrm{~m}^{3} / \mathrm{s}$. In the low velocity regime, the other components of the total air flow resistance due to friction and shock losses are negligible as compared to the filter. Therefore, a quadratic flow resistance characteristic is fitted across the given point for a filter, shown in Figure 1.

\section{AIR FLOW DUE TO NATURAL VENTILATION}

Estimates of the natural air flow rate are determined by the working points at the intersections of the buoyancy pressure and the flow resistance characteristic curves. As shown in Figure 1, a maximum natural air flow rate of $0.8 \mathrm{~m}^{3} / \mathrm{s}$ can be expected at 0.5 year. This air quantity gradually decreases with time, and reaches a low value of $0.6 \mathrm{~m}^{3}$ is by the end of the $100^{\text {th }}$ year of ventilation.

\section{CONCLUSIONS}

This paper provides estimates of the amount of natural air flow which may occur in a potential underground repository for spent nuclear fuel with unsealed emplacement drifts. The method is based on an approximate expression for the time-averaged ratio of $\mathrm{q}_{\mathrm{ai}} / \mathrm{q}_{\mathrm{packaye}}$, i.e. the ratio between the convective and total heat dissipations. This ratio, as a function of air flow rate. can only be calculated using a full-scale thermal analysis of a repository assuming air ventilation. The results of a previous study was used for the present analysis. Further numerical simulations are needed to refine this ratio.

The air quantities obtained for natural ventilation affect air temperatures significantly. The $0.8 \mathrm{~m}^{3} / \mathrm{s}$ air flow rate 


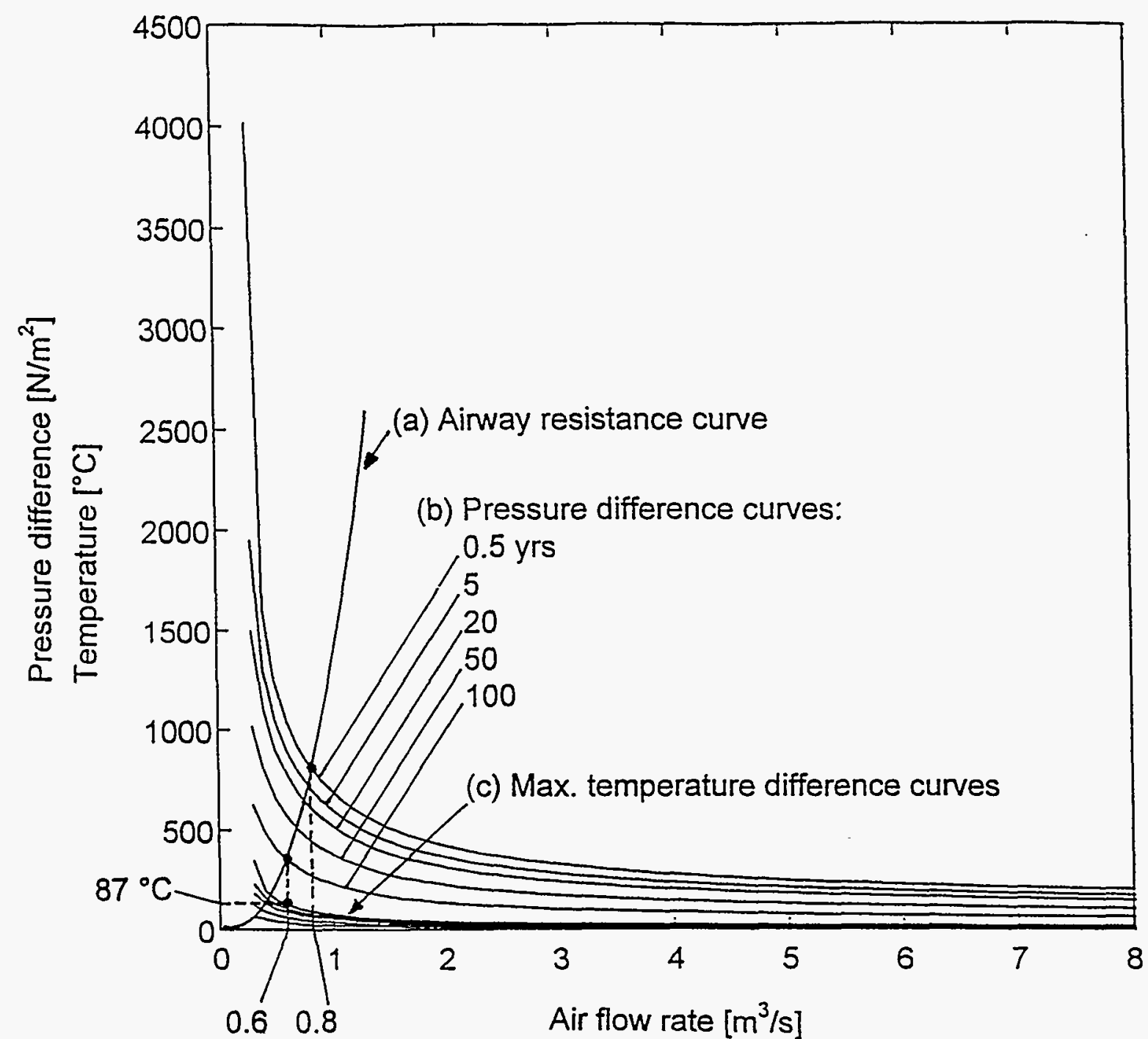

Figure 1. Performace Characteristics of Natural Ventilation: (a) Airway Resistance Curve vs. Airflow Rate; (b) Buoyancy Pressure Generation vs. Air Flow Rate; (c) Maximum Air Temperature Difference Along a Drift vs. Air Flow Rate.

value at the highest $7283 \mathrm{~W}$ dissipation (corresponding to 83 MTU/acre. 26-year-old. "older fuel first" waste load) results in an air temperature increase of $87 \mathrm{~K}$ (or ${ }^{\circ} \mathrm{C}$ ), which is considerably less than the drift air temperature increase of approximately 130 to $160^{\circ} \mathrm{C}$ without ventilation in an otherwise similar repository system (Saterlie and Thomson. 1994).

.Further numerical simulations are needed to check the potential benefit of moisture removal by the small air flow rate generated by natural ventilation. A system study is undenway addressing this issue.

\section{REFERENCE}

1. Danko. G., "Modeling of Ventilation for Emplacement Drift Re-Entry and Rock Drying," Research Report. submitted to MK/DOE. June. 1992, pp. 1-29.

2. Saterlie. S. and B. Thomson. "FY93 Thermal Loading System Study Final Report," Report B00000000-01717-5705-00013, Rev. 01, prepared by the Civilian Radioactive Waste Management System Management and Operating Contractor under Contract Number DE-AC01-9IRW00134, Las Vegas, NV August. 1994. (NNA.940329.001) 


\section{DISCLAIMER}

This report was prepared as an account of work sponsored by an agency of the United States Government. Neither the United States Government nor any agency thereof, nor any of their employees, makes any warranty, express or implied, or assumes any legal liability or responsibility for the accuracy, completeness, or usefulness of any information, apparatus, product, or process disclosed, or represents that its use would not infringe privately owned rights. Reference herein to any specific commercial product, process, or service by trade name, trademark, manufacturer, or otherwise does not necessarily constitute or imply its endorsement, recommendation, or favoring by the United States Government or any agency thereof. The views and opinions of authors expressed herein do not necessarily state or reflect those of the United States Government or any agency thereof. 